\title{
Motivation Factors in the Military: Ethical Leadership and Virtue Ethics
}

\author{
Evaggelia Kiosi \\ National and Kapodestrian University of Athens, Zografou, Greece \\ University of the Peloponnese, Kalamata, Greece \\ Hellenic Police Academy, Athens, Greece \\ Konstantinos M. Karyotakis \\ Technical University of Crete, Chania, Greece \\ Hellenic Police Academy, Athens, Greece
}

\begin{abstract}
This paper focuses on employee motivation factors in military organizations. In the context of the special mission of the military profession, military leadership is approached in an effort to demonstrate the importance and necessity of its ethical dimension in relation to employee motivation. On the motivation factors related to employee personality traits, the paper seeks to demonstrate — through Aristotle's philosophical reasoning (virtue ethics) — that military virtues have to define each member of the Armed Forces in order to fulfill his/her mission. The methodology part of this paper uses the method of interview with permanent officers of the Hellenic Armed Forces in order to prove the strong relationship between ethical leadership, virtue ethics, and employee motivation in the military.
\end{abstract}

Keywords: army, ethics, leadership, motivation, virtue

\section{Introduction}

Organizations and businesses are entities that are inextricably linked to the social framework in which they operate and each time influenced by the specific factors of time and place.

"Organization is a structured social system that consists of groups and individuals working together to meet certain agreed goals" (Greenberg \& Baron, 2013, p. 47).

The role of the human factor in businesses has evolved dynamically in recent years, making human resources and the way they are managed and developed the most important source of sustained competitive advantage for an organization's viability.

"In the modern business environment, the ability of organizations to unleash and exploit the full potential of all their people is of enormous strategic importance and is also considered a great "hidden value"

Evaggelia Kiosi, MPhil., "Ethical Philosophy”, Department of Philosophy, Faculty of Philosophy, Pedagogy, Psychology, School of Philosophy, National and Kapodestrian University of Athens, Zografou, Greece; Department of Philology, School of Humanities and Cultural Studies, University of the Peloponnese, Kalamata, Greece; Master of Science (M.Sc.), School of National Security, Hellenic Police Academy, Athens, Greece.

Konstantinos M. Karyotakis, Doctor of Philosophy (Ph.D.) and Master of Science (M.Sc.), School of Production Engineering and Management, Technical University of Crete, Chania, Greece; Master of Science (M.Sc.), School of National Security, Hellenic Police Academy, Athens, Greece. 
(Bourandas, 2018, p. 249). This ability is intertwined with modern concepts of "empowerment", employee "motivation" and "satisfaction".

Employee motivation is one of the most important issues in management, as it is closely linked to human behavior and performance in an organization (Burandas, 1992, pp. 148-149).

According to one definition, motivation is the force that leads to the following three functions (Karyotakis, 2013, p. 18):

a. Activates people to act.

b. Directs behaviors toward specific goals.

c. Supports the above effort.

"Both theories and research on organizational behavior and examples of several real cases can be useful lessons for creating an environment that will make people feel better and satisfied in the workplace" (Bourandas, 2018, pp. 255-256).

McClelland's expectancy value theory argues that human needs are attainable, evolve through the social environment of the individual, and thus change over the course of life. The basic needs, according to this theory, are three and must be met by each employee through their work (Karyotakis, 2013, pp. 31-32):

a. Need for achievement. It includes personal responsibility, feedback, and moderate risk.

b. Need for affiliation. It involves building friendly relationships, a climate of cooperation, respect, dedication, and affirmation by the group to which one belongs.

c. Need for power. It includes the ability of influence and competitiveness.

Employee satisfaction, motivation, and organizational commitment are positively associated with leadership (Brown \& Trevino, 2006, p. 608), as well as with the individual (employee) as a "vehicle" for motivation. Leadership is about how the chief executive will behave, that is, what kind of leadership style he/she will adopt in the personal relationships with his subordinates, so that they can perform their work effectively and fell satisfaction.

The employee personality is also very important and is largely linked to employee motivation and satisfaction. The theory unit of this paper ultimately moves around two central axes: leadership and individual (employee). The common point of reference in these approaches is the human factor.

In the context of the nature, significance and motivation theories in the modern businesses and organizations, this paper focuses on the phenomenon of employee motivation in military organizations, in the light of ethical philosophy. This is realized in two dimensions: The paper seeks to demonstrate the importance and necessity of ethical leadership, and the timelessness of moral virtues that have to define each member of the Armed Forces in order to fulfill his/her mission.

\section{Literature Review}

\section{Motivation Factors in the Military}

The role of the Armed Forces in the 21st century. The Armed Forces are essential to maintain the inviolable of a country's borders and integrity.

In order for an army to be credible and capable of fulfilling its mission, it is crucial to have a high level of training and preparedness. An army can be used in missions in times of war, crisis, and during peace (dealing with natural disasters, building public utility projects etc.) (Demetroules, 2015, pp. 31-33).

One of the activities that characterize the Armed Forces in the modern international environment concerns 
peace keeping operations for the promotion of democracy, the rule of law, good governance, and human rights.

"It has been argued that the military profession is unique and is the most demanding of all professions" (Lagace-Roy \& Jacob, 2019, p. 339; Cook, 2015, pp. 32-43). Indeed, "every soldier has a duty to be prepared physically and morally for the fulfillment of his/her mission in peace and war" (Hellenic Army General Staff, General Organization Directorate, 1995, Art. 13, Para. 3).

Multi-dimensional decision-making in military organizations underlines the concept of ethics. Nowadays, there is a shift towards virtue ethics applied to fields, including that of military applied ethics: "Military ethics is a species of the genus "professional ethics". That is to say, it exists to be of service to professionals who are not themselves specialists in ethics but who have to carry out the tasks entrusted to the profession as honorably and correctly as possible" (Syse, 2010, p. 119).

"A recent handbook on military ethics states that in any situation where law and ethics set different standards, a member of the military profession will follow the higher standard, inevitably that required by ethics" (Coleman, 2013, p. 268; Olsthoorn, 2019, p. 12).

Three aspects of the military profession: Ethos, honor, professionalism. The words "ethos, honor, professionalism" express tangible, meaningful, and understandable concepts and these are the elements that an army officer needs in order to fulfill his/her duties (Demetroules, 2015, p. 27).

Ethos is a necessary element that has to distinguish both the military leader and the military organization. Military ethics is a concept similar to "warrior ethos", which clearly symbolizes the soldier's constant commitment to the nation he/she serves.

According to Aristotle, ethos is taught through habit, ${ }^{1}$ which is necessary for the acquisition of moral virtue (Nicomachean Ethics (NE), 1993, 1103a 17-18).

Virtues, on the other hand, are acquired first after practicing them (NE, 1993, 1103a 24-25) and represent the desirable traits that have to distinguish all individuals.

All military values are embedded in the notion of honor ${ }^{2}$ which is a vital part of military ethics that indicates what is right to be done.

Professionalism includes knowledge and skills necessary for the officer, a prerequisite for a leader (Demetroules, 2015, p. 29).

Codes of conduct. The values and principles of organizational culture are expressed by rules that strongly determine the decisions and behaviors of individuals in daily practice.

Concerning war, the requirements of ethical behavior during an armed conflict are defined by International Humanitarian Law (IHL), or jus in bello, which is part of the Law of Armed Conflict Law (LOAC). IHL concerns the protection of the "victims" of armed conflicts, particularly the non-combatants, by regulating the rights and obligations of the combatants. ${ }^{3}$

"Clarifying the underpinnings of the just war criteria illuminates exactly what the virtue of justice entails for soldiers. Most fundamentally, it requires sensitivity to the dignity of all persons, and a disposition to respect the rights of those associated with military operations" (Olsthoorn, 2019, p. 34).

\footnotetext{
1 The word ethics comes from ancient Greek ethos ( $\tilde{\eta} \theta o s)$.

2 On military honor and the evolution of the term over the centuries, cf. interesting article Liivoja, R. (2012), "Chivalry Without a Horse: Military Honor and the Modern Law of Armed Conflict" in: ENDC Proceedings 15.

3 The core international treaties concerning the protection of the victims of armed conflicts are the four 1949 Geneva Conventions and relative additional Protocols.
} 


\section{The Ethical Dimension of Military Leadership}

It has been argued that without the study of ethics, understanding of leadership is incomplete: Ethical values always take part in leadership, regardless of whether leaders are clearly aware of the fact. In addition, it has been argued that top leaders recognize their responsibility as the main guardians of their group's values (Demetroules, 2015, pp. 71-72).

In military organizations the leader is equipped with the requisite authority and power, but at the same time he/she is obliged to use this power rationally and ethically (Demetroules, 2015).

In the context of this approach, the philosophical view of virtue ethics highlights the importance of ethical leadership in military organizations, as well as the need the character of each member of the army to be shielded through a virtue ethics-based approach.

\section{Military Virtues}

"The Aristotelian view on virtues underlies most literature on military virtues. What makes virtue ethics especially interesting for the military is its concern with character formation" (Olsthoorn, 2019, p. 2).

"According to Aristotle extravagance or deficiency destroy moral virtues while moderation ensures them" (Kiosi, 2020, p. 62).

"There is a continuous loop between our actions and our character. Our character drives our actions, but our actions come back and shape our character" (Rubel, 2019, p. 128), a view that is also a key position in military ethics, as reflected in key military manuals around the world.

The book Military Virtues describes 14 virtues related to the military: Discipline, Obedience, Loyalty, Courage, Temperance, Integrity, Honesty, Justice, Wisdom, Patience, Perseverance, Humility, Compassion, and Professionalism.

Justice. The virtue of justice, according to Aristotle, is the crown of all virtues, since other virtues are necessary and beneficial to those who practice it, while justice benefits the whole of society. Thus, the justice of a particular human being is offered as a benefit to the fellow citizen, and for this reason it is called ád $\lambda$ ótplov áj $\alpha \theta$ ó (allotrion agothon, social good) (NE, 1993, 1130a 3-5), meaning that it always has a social and political reference (NE, 1993, 1129b 25-28) (Metropoulos, 2014). Given the nature of the virtue of justice, cultivating just military personnel will require the cultivation of sensitivity to the dignity and rights of all persons (human beings).

To Aristotle, becoming righteous is not enough to know what justice is, but to continually do righteous acts, thus addicting the proper part of the soul. Thus, justice is defined as $\dot{\varepsilon} \xi \iota \varsigma$ (exis, habit) according to which one does and wants to do the righteous (NE, 1993, 1129a 6-9). Yet another act to be just, it should not be done by coercion or ignorance, but must be predisposed and chosen as an end in itself (NE, 1993, 1144a 13-20) (Metropoulos, 2014).

Discipline. Discipline is the basic military virtue and the primary power that keeps the army consistent. All other military virtues are rendered useless without the submission of individual will to the commands of the leader (Hellenic Army General Staff, 1995, Art. 13, Para. 3).

Discipline is internal, when it derives from a sense of individual dignity and honor, from a consciousness of responsibility and a moral obligation to accomplish the common task. On the contrary, discipline is external when it is based on the fear of punishment or the hope of reward (Hellenic Army General Staff, 1995, Art. 10, Para. 4). 
On the other hand, discipline refers to what is called "a phenomenon of self-consciousness". This kind of discipline is called "self-discipline" and can be regarded as a moral or spiritual trait manifested in human behavior. It overlaps to some extent with other virtues, such as obedience, self-control, and consistency (Robinson, 2019, p. 313).

\section{Methodology: Measuring Professional Motivation and Satisfaction in Military Organizations (Qualitative Study)}

In January 2020, an original survey was conducted ${ }^{4}$ in order to record the views of officials of the Hellenic Armed Forces on the phenomenon of employee motivation in the military. The specific objectives of the research were:

a. Studying of the kind of leadership that is considered appropriate by the military personnel.

b. Investigating the attitude and reaction of militaries towards ethical leadership in the army.

c. Recording of parameters that appear to contribute to the phenomenon of employee satisfaction and motivation in military organizations.

d. Demonstrating the need for the development of military virtue in the framework of design and implementation of active policies to address the phenomenon of employee satisfaction and motivation in the military.

The survey population consisted of 20 Greek permanent military officers, 10 men and 10 women, aged from 40 to 50 years, with at least 15 years of professional experience, working in the Attica basin (Athens). Structured interviews were completed using a 15-minute-duration questionnaire.

\section{Results and Discussion}

The survey summarized the following data:

a. The content attributed to the term "good" military leadership by both male and female officers refers to the purpose, vision, inspiration that comes from the leader's personality, the leader's commitment to the mission, the command by example, excellent vocational training, and leader ethos.

b. Leadership that was generally cited as "ethical" in military organizations is distinguished by justice, respect for human dignity, honesty, morality, commitment to the mission, consistency of words and deeds, sincerity, selflessness, impartiality, and integrity.

c. Regarding the appropriate leadership style on motivation, all officers referred to inspiration, determination, justice, ethos, courage, and professionalism that must characterize the military leader.

d. Regarding the conditions for giving one's best in job, all officers referred to moral reward, recognition of subordinates, and inspiration in the face of the leader, confidence, and goal-setting.

e. The basic needs associated with motivation at work relate to the need for achievement and need for affiliation. This highlights goal-setting as a key parameter of effective management in terms of employee satisfaction.

f. The key feeling that plays the most important role in achieving high performance at work is, for both male and female officers, competence, autonomy, and sense of belonging. The prevailing sense of competence

\footnotetext{
${ }^{4}$ The research has been conducted for the needs of Kiosi, E. (2020), "Human Resources Management and Motivation: Ethical Leadership and Virtue Ethics as Motivation Factors in the Military" (Thesis, School of National Security, Hellenic Police Academy).
} 
highlights the need for employees to continually acquire knowledge and skills relevant to the subject of their work.

g. Both male and female officers attribute discipline, justice, and command by example as basic virtues for a military leader.

h. Most of the answers to the questions included the term "justice" as a characteristic of "good" and "moral" military leadership as well as a basic military virtue.

i. The terms "ethos" and "ethical reward" were answered, by priority among all the officers questioned, in the majority of the questions.

j. "Inspiration" and "command by example" parameters were seen as key features of a military leadership that activates employee motivation.

k. The answers, in general, have highlighted "justice" and "discipline" as key concepts in the military profession.

\section{Conclusion}

According to the research conducted for the needs of this paper, "ethos" and "ethical reward", "inspiration", and "lead by example" are prioritized by military personnel as prerequisites for effective leadership and employee motivation in practice. These data indicate that military leadership embodies the concept of ethical leadership, and the ethics of military leadership is directly related to employee motivation.

The most important military virtues are those of discipline and justice, key concepts that (must) define the military profession and (must) distinguish both the leader and the followers.

The aforementioned relationship between ethical leadership and virtue ethics may be the subject of further research focusing on the character both of the military leader and the followers in the context of studying the phenomenon of employee motivation.

Education is crucial for shaping human character. Prevention must focus on human factor and need the help of education, as it is vital for the development of humanity. According to Aristotle, the factors that contribute to the foundation of the moral character are addiction and learning. The modern bet on systematic education, both in public schools and in military academies, should regard shaping a collective perception capable of putting responsibility and consistency at the top of a human rating system.

The "soft power" of military education provided in the light of ethos, justice, and honor can universally approach and address the goal of effective military ethical leadership and employee motivation in the military.

\section{References}

\section{References in Greek}

Aristotle. (1993). Nicomachean ethics. Athens: Cactus Publications.

Bourandas, D. (1992). Management. Organizational theory and behaviour. Athens: Team.

Bourandas, D. (2018). Successful leader and manager. Practices, methods, tools for outstanding results through the team. Athens: Psychogios.

Demetroules, D. (LtGen ret). (2015). Military ethos and leadership. Athens: Hellenic National Defense General Staff.

Greenberg, J., \& Baron, R. A. (2013). Organizational psychology and behavior. (A. S. Antoniou, Ed. \& Trans.). Athens: Gutenberg.

Hellenic Army General Staff, General Organization Directorate. (1995). Military regulation 20-1, general rules of service in the army. Athens: Hellenic Army Printing Press.

Karyotakis, K. (2013). Job satisfaction and employee satisfaction (Scientific paper, Master's Degree Program in Organization and 
Management, Department of Production Engineering and Management, Technical University of Crete, 2013).

Kiosi, E. (2020). Human resources management and motivation: Ethical leadership and virtue ethics as motivation factors in the military (Thesis, School of National Security, Hellenic Police Academy, 2020).

Metropoulos, N. P. (2014). The main virtues and Aristotle ethics. Erkyna, Review of Educational and Scientific, (2), 76-86.

References in English

Brown, M. E., \& Trevino, L. K. (2006). Ethical leadership: A review and future directions. The Leadership Quarterly, 17, 595-616.

Coleman, S. (2013). Military ethics. UK: Oxford University Press.

Cook, P. (2015). A profession like no other. In G. Lukas (Ed.), Routledge handbook of military ethics (pp. 32-43). Abingdon: Routledge.

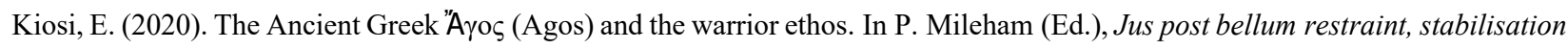
and peace. Series: International studies on military ethics, Volume. 6 (pp. 48-73). Leiden: Brill/Nijhoff.

Lagace-Roy, D. \& Jacob, C. (2019). Professionalism. Overview: Military excellence through practice. In M. Skerker, D. Whetahm, and D. Carrick (Eds.), Military virtues (pp. 337-347). Hampshire: Howgate Publishing Limited.

Liivoja, R. (2012). Chivalry without a horse: Military honor and the modern law of armed conflict. ENDC Proceedings, 15, 75-100.

Olsthoorn, P. (2019). Military virtues and moral relativism. In M. Skerker, D. Whetahm, and D. Carrick (Eds.), Military virtues (pp. 1-14). Hampshire: Howgate Publishing Limited.

Robinson, P. (2019). Discipline. In M. Skerker, D. Whetahm, and D. Carrick (Eds.), Military virtues (pp. 311-318). Hampshire: Howgate Publishing Limited.

Rubel, R. (2019). Wisdom. In M. Skerker, D. Whetahm, and D. Carrick (Eds.), Military virtues (pp. 127-132). Hampshire: Howgate Publishing Limited.

Syse, H. (2010). What should we mean by "military ethics"? Journal of Military Ethics, 9 (2), 119-122. 